\title{
Erratum to: Molecular Characterization and Determination of Some Biochemical Properties of Endemic Serratula olygocephala Growing in Adiyaman
}

Yener TEKEL $\dot{I}^{*}$, Ahmet ÖZKAYA², Ahmet Zafer TEL ${ }^{3}$, Görkem DENIZ SÖNMEZ1 , Süleyman AKOCAK¹

\author{
${ }^{1}$ Faculty of Pharmacy, Adıyaman University, Adıyaman, Turkey. \\ ${ }^{2}$ Department of Chemistry, Faculty of Science and Letters, Adryaman University, Adiyaman, Turkey. \\ ${ }^{3}$ Faculty of Agriculture, I $\breve{g} d \imath r$ University, I $\breve{g} d \imath r$, Turkey
}

ORCID ID: Yener TEKELI: https://orcid.org/0000-0003-1524-457X; Ahmet ÖZKAYA: https:/ /orcid.org/0000-0002-0173-3084; Ahmet Zafer

TEL: https:/ / orcid.org/0000-0002-1204-3839; Görkem DENIZ SÖNMEZ: https:/ / orcid.org/0000-0002-3613-0195; Süleyman AKOCAK: https://orcid.org/0000-0003-4506-5265

\begin{tabular}{llll}
\hline Received: 06.12.2021 & Accepted: 10.12 .2021 & Published online: 10.12 .2021 & Issue published: 31.12 .2021 \\
\hline
\end{tabular}

Erratum to :Comm. J. Biol. 3(1): 32-36

DOI $\quad$ : https://dergipark.org.tr/tr/pub/commagene/issue/46593/559626

Son okuma sırasında Tablo 1'de ve eklenmesi gereken referanslar gözden kaçmış olup aşağıda düzeltilmiştir. Aynı zamanda Tablo 2'de PZR reaksiyon koşullarında tabloda sütunlar arasındaki kayma gözden kaçmış olup aşağıdaki şekilde düzeltilmiştir.

\subsubsection{PZR sonuçlarının dizilenmesi}

Örnekler, BM Laboratuarı (Ankara) gibi dizi analizi yapan ticari kuruluşlara hizmet alımı şeklinde gönderildi. Elde edilen diziler; Windows 95/98/NT/2000/XP için yazılmış olan BioEdit (Hall, 1999) biyolojik dizi sıralama editörü ile kontrol edildi. Sol (5', forward) ve sağ (3' revers) primerler ile okunan diziler eşleştirildi. National Center for Biotechnology Information (NCBI, http://www.ncbi.nlm.nih.gov) veri bankasında BLAST analizi ile hangi bitki oldukları teyit edildi ve veri bankasındaki yakın benzerlik gösterdiği diğer bitkiler kullanılarak Paup 4.0 (Swofford, 2000) ve BioEdit (Hall, 1999) programları yardımıyla filogenetik analiz yapıldı.

Tablo 1. PZR' de Kullanılan Primerler ve Özellikleri

\begin{tabular}{|c|c|c|c|}
\hline Primer & Nükleotid Dizisi(5'-3') & Tm Değeri & Referans \\
\hline ITS-4 & TCCTCCGCTTATTGATATGC & $52.1^{\circ} \mathrm{C}$ & (White et al., 1990) \\
\hline ITS-5 & GGAAGGAGAAGTCGTAACAAG & $55.0^{\circ} \mathrm{C}$ & (Sang et al., 1995) \\
\hline TrnL-F & ATTTGAACTGGTGACACGAG & $55.0^{\circ} \mathrm{C}$ & (Taberlet et al., 1991) \\
\hline TrnL-R & GGTTCAAGTCCСТCTATCCC & $55.0^{\circ} \mathrm{C}$ & (Taberlet et al., 1991) \\
\hline \multicolumn{4}{|c|}{ Tablo 2. PZR Reaksiyonları } \\
\hline Basamak & Sicaklık & Zaman & Devir Sayısı \\
\hline Ön 1sitma & $94^{\circ} \mathrm{C}$ & 5 dak. & 1 devir \\
\hline 1. basamak & $94^{\circ} \mathrm{C}$ & $45 \mathrm{sn}$. & \\
\hline 2. basamak & $50^{\circ} \mathrm{C}$ & $45 \mathrm{sn}$. & 35 devir \\
\hline 3. basamak & $72^{\circ} \mathrm{C}$ & 2 dak. & \\
\hline 4. basamak & $72^{\circ} \mathrm{C}$ & 10 dak. & 1 devir \\
\hline 5. basamak & $4^{\circ} \mathrm{C}$ & 25 saat & \\
\hline
\end{tabular}

\section{Kaynaklar}

Sang, T., Crawford, D.J., \& Stuessy, T.F. (1995). Documentation of reticulate evolution in peonies (Paeonia) using internal transcribed spacer sequences of nuclear ribosomal DNA: Implications for biogeography and concerted evolution. Proceedings of the National Academy of Sciences of the United States of America, 92, 6813-6817. https://doi.org/10.1073/pnas.92.15.6813

Taberlet, P., Gielly, L., Pautou, G., \& Bouvet, J. (1991). Universal primers for amplification of three non-coding regions of chloroplast DNA. Plant Molecular Biology, 17, 1105-1109.

Tekeli, Y., Özkaya, A., Tel, A.Z., Deniz Sönmez, G., \& Akocak, S. (2019). Molecular Characterization and Determination of Some Biochemical Properties of Endemic Serratula olygocephala Growing in Adiyaman. Commagene Journal of Biology, 3 (1), 32-36. https://doi.org/10.31594/commagene.789682
White T. J., Bruns, T., Lee, S., \& Taylor, J. (1990). Amplification and direct sequencing of fungal ribosomal RNA genes for phylogenetics, In: M Innis, D Gelfald, J Sninsky, T White, (eds.) PCR Protocols: A Guide to Methods and Applications. pp. 315-322. San Francisco: Academic Press. https:/ / doi.org/10.1590/0102-33062015abb0267 